\title{
Research with Life Stories in the Production of the History of Science Education: The Photobiographical Device as a Resource for the Understanding of Social Experiences
}

\author{
Rodrigo Cerqueira do Nascimento Borba ${ }^{(1)}$ Brazil \\ Sandra Escovedo Selles ${ }^{(1)}$ Brazil
}

The activation of diversified historical sources and methodological approaches have been requested to the production of a new socio-historical knowledge concerning the historical constitutions of the school subjects of science and biology. This approach allows the understanding of controversies and disputes about these subjects. The present paper aims to present and problematize the use of an investigative resource developed in the field of Social sciences and still unusual in the science education studies with historical perspectives: the photobiography. This device combines references from Sociology, History of Education and Curriculum. In the paper, the photobiography dialogues with a research on the social trajectory of a science teacher whose professional practices were in tune with the assumptions of the "Science Education Innovation Movement" of the 1960s and 1970. The photobiography device is used for triggering memories and the production of other meanings of science teaching at that milieu.

Keywords: science education; photobiography; curriculum.

\section{Introduction}

This text integrates a broader research that is inserted in the field of curriculum studies - specifically, the history of the school subjects of science and biology - and focuses on the life story of a Secondary Education teacher working in Rio de Janeiro state schools in the second half of the 20th century. For this purpose, the article uses theoretical and methodological references from the field of Sociology to problematize elements of her professional trajectory in dialogue with the History of Education and the Curriculum. In particular, our focus is on the relevance of exploring biographical studies, mobilizing these references, in order to contribute to the understanding of the history of the aforementioned school subjects.

The interest in a specific teacher is due to the fact that she guided her professional practice in line with the "Science Education Innovation Movement", whose importance is found in literature records such as Abrantes and Azevedo (2010), Azevedo (2020), Cassab (2015), Fracalanza, Amorosino and Gouvea (1987), Gomes (2008), Gomes, Selles and Lopes (2013), Krasilchik (2000) and Marandino, Selles and Ferreira (2009). This Movement was strengthened between the 1960s and 1980s, focusing on school subjects of scientific nature, especially on the production of teaching materials, experimental 
teaching and methodologies inspired by scientific practices. This is because the "Science Education Innovation Movement" was articulated with educational purposes that aimed at increasing the country's scientific-technological production and fostered the development of other standards for science education and for the training of teachers in the area (Ayres, \& Selles, 2012; Azevedo, Selles, \& Lima-Tavares, 2012; Fracalanza, 2009; Krasilchik, 2000).

Within the scope of this "Innovation Movement", the teacher whose career we chose to tell created teaching practices that have projected her as an unforgettable and remarkable teacher ${ }^{1}$ (Lopes, 2013, 2016). This is Nilza Bragança Pinheiro Vieira, a teacher who taught sciences from 1963 until 1995 at the Municipal School Camilo Castelo Branco (EMCCB), located in the neighborhood of Jardim Botânico, in the south of the city of Rio de Janeiro. According to the evidence already gathered around her social trajectory (Dubar, 1998) ${ }^{2}$, our interest is justified for the following reasons: Nilza stood out as a participant in the Guanabara Science Center (CECIGUA) in the 1960s and 1970s and as the author of science textbooks in the 1970s. She was also part of a community of teachers in curricular projects in the 1980s and was one of the pioneers in carrying out Environmental Education activities in the city, as indicated by Scarton and Selles (2012).

The study is also supported by the recognition that there is a demand for sociohistorical studies on the science school subject that not only question its constitution, its ties with the sciences of reference and with other forms of knowledge socially disseminated (Santos, \& Selles, 2014), but also that are directed to the understanding of teaching trajectories in an articulation with the transformations in society (Ayres, \& Selles, 2012). In this way, we use the device of photobiography to get closer to the concepts that made Nilza Vieira's performance stand out.

We chose to explore the professional trajectory of this teacher in order to get closer to the concepts that made her performance stand out and her connections with the history of the science school subject. For this purpose, we use photobiography, a methodology of biographical work that, by mixing narrative and image, provides a reflective exercise for both the interviewee - who will produce meanings by weaving and connecting their memories -, as well as for the interviewer, who will seek to learn and interpret them together with the interviewee (Bruno, 2014). Furthermore, in tune with Bourdieu (1996) and Bourdieu (2006), we envision photographs as objects suitable for sociological readings from the analysis of the social uses, the meanings attributed to this

1 Lopes' $(2013,2016)$ research on the teaching profession in a historical perspective indicates processes of identification of the teaching staff of educational institutions that allow certain teachers to stand out and make them unforgettable. The prestige stems from their appeal to the "vocation" as an explanation for their professional choice, level of teacher education, the way in which they began their career, the social value of their school subjects, their articulation with sociability networks and instances where they circulated, in addition to the repercussion and realm of educational materials they produced.

2 According to Dubar (1998), the analysis of the trajectories of social subjects must articulate multiple aspects of the biographical process in order to understand their identity constructions. This means associating objective social practices and positions and the marks of subjectivities in the narratives produced in life story interviews. 
type of record and the photographic practices themselves, which should not be seen as restricted to technical or aesthetical aspects.

For this reason, this text is organized in such a way that, in the following section, a brief questioning about the powers and limitations of biographical work will be presented. Then, we will present the photobiographical device built together with Nilza Vieira. From such device, we weave some reflections based on her narrative and mobilize methodological reservations. At the end, we will point out some considerations as a conclusion. With this text, we seek to engage in an exercise that can contribute to the research in the field of history of science education in Brazil, considering that both the history of curriculum and the history of school subjects have been hybridized and tensioned by different theoretical and methodological perspectives, as pointed out in Cassab (2010) and Fonseca, Xavier, Vilela and Ferreira (2013).

\section{Working with photobiographical devices}

The article is theoretically and methodologically situated in the perspective of biographical studies and the focus of the research presented here is based on an autobiographical narrative by Nilza Vieira. Such narrative was produced in a statement that followed the qualitative procedures recommended for works with Oral History (Delgado, 2011) and with narratives about teachers' life histories (Goodson, 2015). The interview was conducted at the teacher's residence, recorded on audio and lasted almost four hours. Under the semi-structured format, the interview aimed to apprehend the teacher's professional trajectory in the following aspects: social origins; initial and continued training process; admission to teaching and professional establishment; insertion in networks of sociability and solidarity; curricular productions.

Considering that the work with the trajectories of teachers requires the crossing of different historical sources (Goodson, 2015; Lozano, 1996), in this study, we chose to practice the use of photobiography. The photobiographical device is built from a selection of imagery records from a biographical collection. Among the photographs made available to the researcher, the interviewee to be biographed selects those that are related to their life story and chooses the most significant ones in their view. Then, the interviewee is invited to tell a story that integrates the selected images, using elements of their personal and professional trajectory as an integrating framework to produce an autobiographical narrative (Bruno, 2014). Thus, it is worth remembering the perception of Delory-Momberger (2012) when she argues that the production of biographical studies is an invitation for the other to reveal themselves by representing and re-presenting the past, since becoming biographical is not something given, which makes it impossible for one to know the social subjects before hearing them in this type of research. The researcher also participates in the process of constructing the biography, as it is the result of the dialogical interaction built at the time of the interview production, the transcription of orality and the interpretation from the researcher's perspective, which crosses the narrative to other sources (Goodson, 2015; Portelli, 1997). 
In our research, we followed the guidelines briefly mentioned above and presented in more detail by Bruno (2014) to encourage Nilza Vieira to revisit her role as a science teacher from photographs taken in the 1970s and kept in her personal biographical collection. It was our purpose to instigate a narrative that contemplated her views on science education, as well as her teaching experience, some teaching practices developed and her main conceptions about what it is to learn and teach. However, we also consider that the capture of the moments that comprised the photobiography obtained, the preservation of the photographs and the selection of images operated by the teacher were not performed in a neutral way. The understanding that the records discussed here may not have been produced accidentally or to be ephemeral (Bourdieu, \& Bourdieu, 2006) is a methodological precaution that reduces the risk of monumentalization ${ }^{3}$ (Le Goff, 1996) of Nilza Vieira's actions and of undertaking an uncritical analysis of her memories.

In his text on the biographical illusion, Bourdieu (1996) criticizes subjectivist approaches that do not consider the objective conditions that would explain the course of subjective experiences, thus contributing to an illusory conception of social reality. However, if, on the one hand, the biographical genre is a target of criticism for the risk of attributing rationalities to life histories - which may constitute narratives that often rely on coherences and linearities that never effectively existed -, we agree with Sabina Loriga (1998) on the importance of biographical studies for the production of a history of experiences, daily life and minorities. Among the different biographical typologies listed by Levi (1996), we consider that the narrative modality of biography and context is the one that most closely matches our research approach. In this case, the specifics of the biography are preserved, "however, the time, the environment and the ambience are also highly valued as factors capable of characterizing an atmosphere that would explain the singularity of the trajectories" (Levi, 1996, p. 175).

Furthermore, the use of this methodological device for the mobilization of narrative capital ${ }^{4}$ (Goodson, 2007) around the curricular practices established by Nilza Vieira is in agreement with the prerogatives that Daniel Bertaux $(2009,2014)$ gives to biographical work. For Bertaux $(2009,2014)$, the social worlds do not allow the autobiographical narratives produced by the subjects to be seen in isolation, since they build their stories from what is inherited and lived in the scenarios in which they are inserted. In other words, the subjects are not detached from time and social space: narrative capital is mobilized based on their experience, judgement and the meanings that they have built over them.

For this author, when building memories, provoking narratives and comparing the courses of action of individuals, the researcher must develop a narrative listening

\footnotetext{
3 According to Le Goff (1996), memories are selective constructions. Thus, not everything is registered by social subjects or is enunciated when remembered. Because they vary according to the way they are articulated, structured and expressed, memories must be a point of constant attention for the researcher.

4 Goodson (2007) elaborates and operates with this concept inspired by the work of Pierre Bourdieu. Narrative capital is that related to someone's ability to think and theorize about their own life story narratives, producing meanings for experiences and negotiating meanings for future projects.
} 
that allows the observation and understanding of the social game from the other's perspective. Such movement allows networks of social, cultural and economic positions / relations to be recognized and unveiled. In addition, Bertaux $(2009,2014)$ argues in favor of abandoning the idea that qualitative research, like biography, is flawed just because it is strongly anchored in subjectivities, while the objectivity of quantitative research per se would make it more credible and true. We agree with this criticism to the objectivist perception that sees narratives always as illusory. For this reason, we have undertaken the exercise presented below.

\section{Writing stories and recording experiences with photobiography}

The statements to be presented in this text were extracted from an interview conducted by the first author at Nilza Vieira's residence in early 2019. The interviewee signed the consent and the assignment of rights to the oral testimony and authorized her nominal identification when using the information provided. In addition, the use of photographs from her personal collection for research purposes and its publication in the materials for its dissemination, such as articles and complete works, were also allowed.

At the age of 19, in 1956, Nilza Vieira enrolled in the natural history undergraduate course at the University of Brazil (UB) - currently the Federal University of Rio de Janeiro -, from where she graduated in 1960. In the following year, she took a specialization course in Genetics and Evolution at UB, supervised by Antônio Geraldo Lagden Cavalcanti, during which she did an internship at the University of São Paulo, supervised by Oswaldo Frota-Pessoa. Married to the physicist Cândido Oromar Figueiredo Vieira ${ }^{5}$ - a professor at UB and at the Guanabara Science Center (CECIGUA) -, Nilza was a student, professor and coordinator of courses offered at CECIGUA throughout the 1960s and 1970s. She worked at the municipal public education system of Rio de Janeiro from 1963 until 1997. During most of that time, she was a science teacher at EMCCB, in the Jardim Botânico neighborhood. In the 1970s and 1980s, she worked on teacher training, receiving trainees in biological sciences courses, some of whom had been her students in previous years. Under her supervision, they participated in a variety of teaching activities. Among Nilza's curricular productions, there is a textbook and its respective methodological guide to support the work of schoolteachers (Vieira, Vieira, \& Silva, 1970, 1972).

The collection of photographs that portrayed her activities as a science teacher contained 41 images. Among these, to compose the present photobiography, the teacher selected 13 pictures, all related to field trips to Urca Beach that she had organized. Such selection was carried at the request of the interviewer, who asked the interviewee to choose, from the photographs presented, those that could help her tell a story about her teaching practices. The researcher did not give an opinion on which records should or should not be chosen. It was not possible to know if all the photographs were taken at

5 He passed away in April 1971. 
the same time or if they are records of different meetings. However, on the back of one of the images, she had marked the year 1971, a possible year for carrying out the activity revisited in the interview and which coincides with the memories brought during her testimony.

It is worth mentioning that photographs are often produced to eternalize and solemnize activities or practices that are not routine, with the intention of fabricating a certain representation of oneself or of a social group in which the subject who photographs or is photographed is inserted. Thus, it is interesting to see the images below as sources that allow the visual record of relationships and social roles that one wishes to preserve (Bourdieu, \& Bourdieu, 2006).

It should also be mentioned that fieldwork classes are one of the strong curricular traditions within science and biology education, inherited from natural history traditions (Marandino et al., 2009). In this context, we are faced with the reflections of Claude Dubar (1998), who understands that social trajectories must be problematized from the relations between individual and society and analyzed in association with the objectification and subjectification processes that refer, respectively, to the objective social positions occupied during life and the subjective elements that can be expressed in biographical reports. Therefore, the observation that Nilza Vieira graduated in 1960 from the natural history course at the University of Brazil may provide us some hints to the reasons that field trips were so valued in her professional practice to the point that the activity records at Urca Beach are listed for the production of the photobiographical device. This selection also indicates that Urca Beach has become and can be assumed as a place of memory ${ }^{6}$ (Nora, 1993) presented in the teacher's narrative.

Interestingly, her photobiographical narrative begins with the memory of an experienced science teacher she admired, the father of a friend of her husband. From the memory of the stories told by this gentleman, named by her as doctor Moisés, and bringing up the feeling of positive recognition for those who like to teach, Nilza Vieira begins her narrative. Throughout this section, we will present the photographs according to the order she signaled during the production of the testimony, intermingling the transcriptions with the images and some considerations. All the quotes presented in this paper come from an interview with Nilza Bragança Pinheiro Vieira granted to the first author on January 3, 2019 at his residence. The teacher begins her testimony by taking the third person singular. This way of narrating can be understood as the intention to share the place of observer with the interviewer, probably to express herself more freely and to mark her self-judgment on the scenes fixed by photography:

Once upon a time there was a girl dazzled by teaching and she met a boy who was also dazzled by teaching. She liked biology and he enjoyed physics. He had a friend, who became a mutual friend, and was the father of a friend who was also a science teacher.

6 According to Nora (1993), places of memory are material, symbolic and functional spaces characterized by a ritualized and non-spontaneous aura that transforms memory into history. The places of memory, in addition to preserving and assigning meanings to collective memory, also corroborate the invention or reinforcement of identities. 
So what fascinated the boy - Cândido - in this man was that he knew how to teach. And the cases he told: a thousand cases about the classroom, how he taught this and that. And then he [Cândido] took, as if to show a treasure, he took the girl, Nilza, to meet Doctor Moisés and she was also fascinated. We spent nights listening to him tell his stories in the classroom and, at the same time, she was building her teaching practice by what he said.

From this initial testimony, in which Nilza mobilizes so many memories that would justify part of her fascination with teaching, it is worth reaffirming life stories as fruitful sources for research on teaching and teacher training. This is because they allow the apprehension of dimensions of the trajectories of teachers that help us to understand their teaching practices and their socialization spaces (Lelis, 2014). Here, we can see how important it was for Nilza Vieira to be in touch with a more experienced, regarded as a professional model to inspire her.

Furthermore, because we work with subjectivity and memory in this narrative about the teacher's life story, we have the opportunity to overcome essentialist representations of what it was to be a teacher for her, while the challenge becomes to think like her life story communicates with other stories, with lived experiences and with the contexts that forged them (Lelis, \& Nascimento, 2010). Continuing with the elaboration of the photobiography, she expressed a narrative that showcased a sense of professional fulfillment, when Dr. Moisés, the teacher she admired so much, went to attend one of her fieldwork classes at Urca Beach (Figure 1):

And her greatest glory was that years later he was an observer of her practice. More than an observer, he went there. Even older, 10 years older, to learn what her students were teaching about the sea. He leaned over to look in the basin at what they were showing and teaching. And in her head, a film was shown, seeing what he must have been thinking: she went there, a university student dazzled by his story, and now he is living her story [emphasis added by the authors].

In view of Figure 1 and the teacher's initial considerations, we can envision the activation of this record of Doctor Moisés as a trophy that connotes the social importance of the teaching practice developed by Nilza Vieira. This is one of the uses of photographs pointed out by Bourdieu and Bourdieu (2006) that can attract our attention: the activation of records and the elaboration of speeches that can serve to enhance the person represented in the photos. As suggested by the authors, Nilza chooses to narrate herself "from the outside", using the third person singular. 


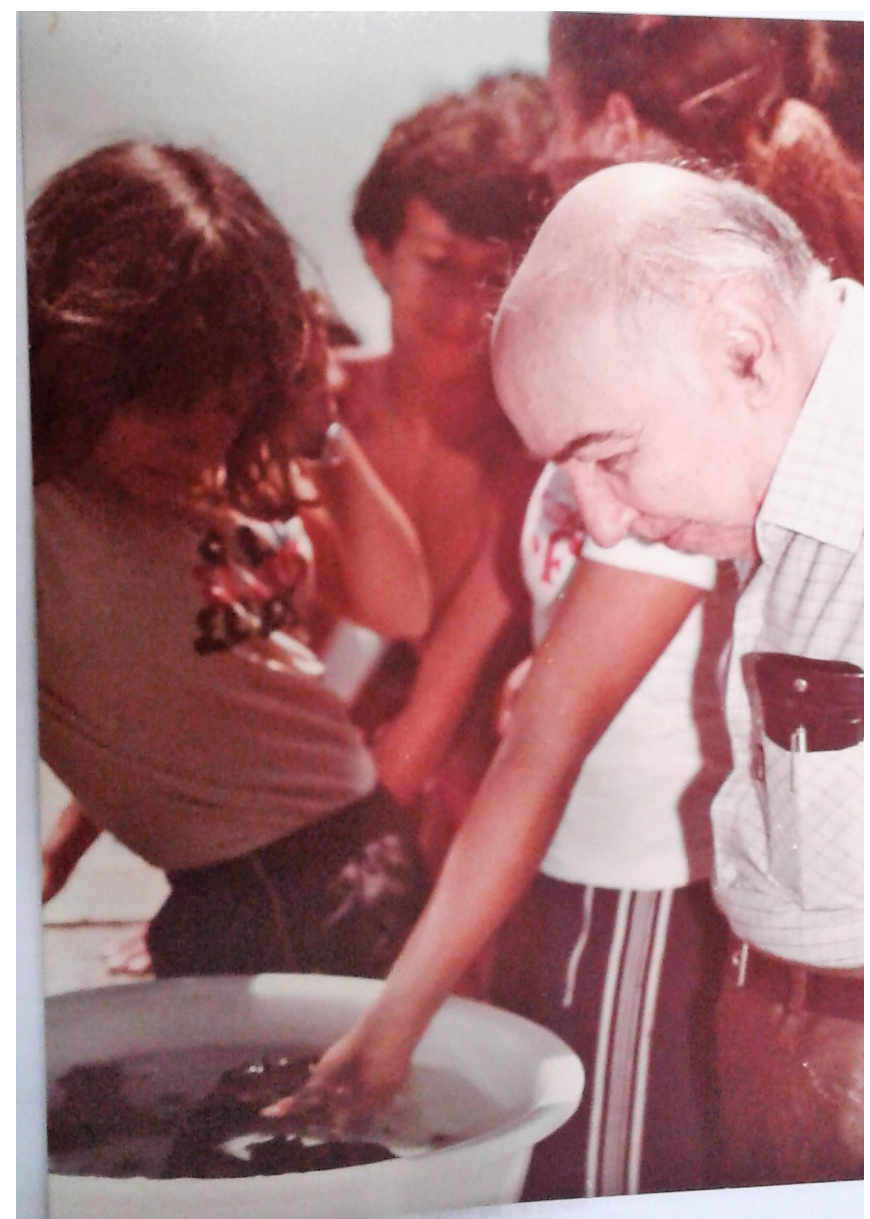

Figure 1. Doctor Moisés, a professional admired by Nilza Vieira, visits her fieldwork class

Source: Nilza Vieira’s personal photographic collection.

Goodson (2007) argues for the relevance of mobilizing aspects of teachers' life stories and professional trajectories when studying the history of school subjects, as this makes it easier to establish interconnections between subjects and social structures. This author also challenges us to "see the individual in relation to the history of his time, allowing us to face the intersection of life story with the history of society, thus clarifying the choices, contingencies and options that the individual faces" (Goodson, 1992, p. 75). Thus, perhaps we understand why Nilza Vieira, a woman, widow of a physicist and university professor, mother and Secondary School teacher, has shown so much pride when narrating herself in the third person singular. Confusing herself with the character she created for the photobiography, when telling about the teaching work she developed she explains the success she made when she stopped her car at Urca Beach with the materials for the fieldwork class (Figure 2):

And one part of her story is one of enormous pride. She had a big car, of course, I never had a new car, but it was a big car. The big car stopped at the edge of the sidewalk, near the wall in Urca, and a lot of things came out of the car. 


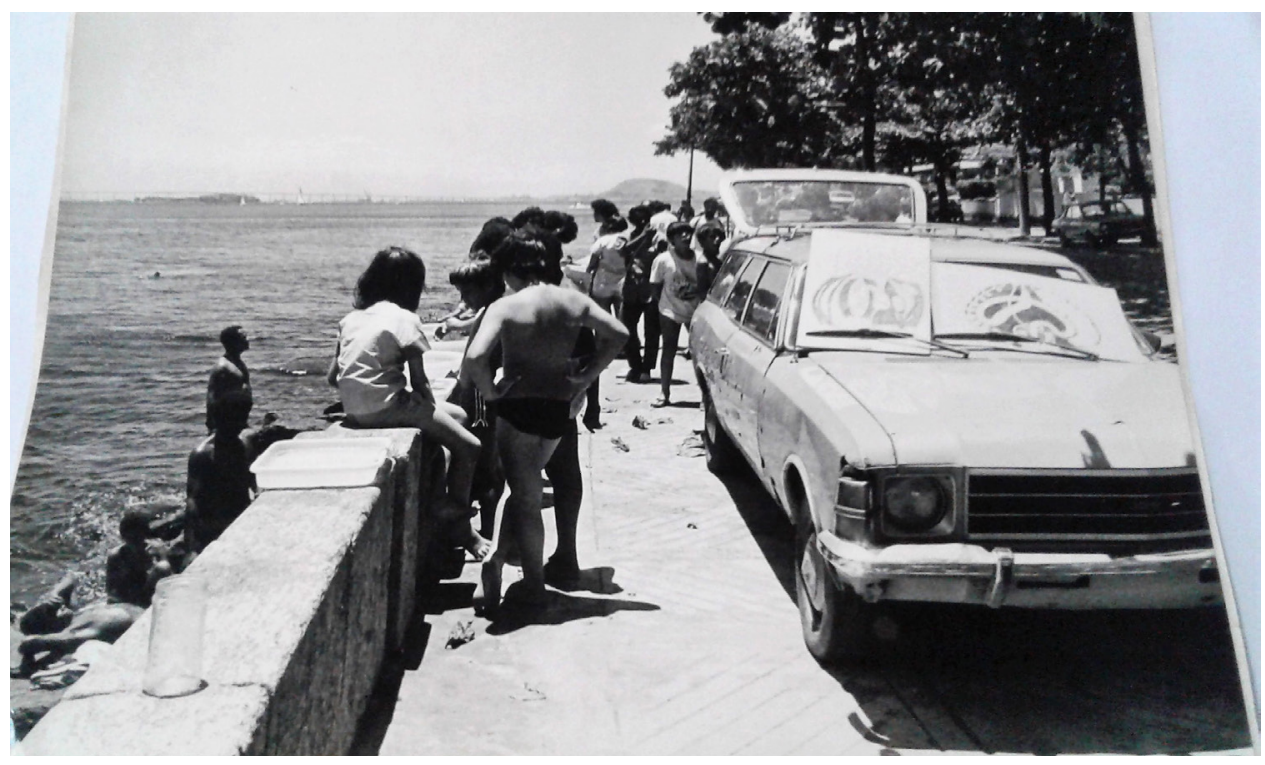

Figure 2. Students and interns near the wall at Urca Beach around Nilza Vieira's car

Source: Nilza Vieira’s personal photographic collection.

It is important to avoid a naive look at memories, whether these are individual or collective, since they are always selective (Le Goff, 1996). Therefore, we must pay attention to the fact that in Nilza Vieira's narrative, it is presented a type of fieldwork class dynamics that is difficult to materialize in an open and external environment to the school space, with the risk of accidents, with strangers surrounding the students and with the need for material and logistical resources for collecting and maintaining marine animals as shown in figures $3,4,7,8,10,11$ and 12 . After all, disputes, constraints and hesitations are often not brought up by who remembers or who wants to frame memories ${ }^{7}$ (Pollak, 1989, 1992), as it may have happened for the production of this photobiography, considering the emphasis given to the free movements of students and the absence of adults monitoring them. Nor can it be ignored that, however spontaneous they may seem, photographs are records manufactured to deliberately present behaviours that exalt specific feelings and values according to the purposes of the subjects involved with the portrait (Bourdieu, \& Bourdieu, 2006). Therefore, it is prudent not to forget this by continuing to read the images and the transcript:

The amazing thing is that those who came in the car were only children and young people, she was the only adult. And then things were scattered, but there was order. Nobody took care of anyone, each one took care of him or herself and helped the other. They quickly separated, each person knew what to do.

7 Michael Pollak $(1989,1992)$ triggers the category of framed memory to refer to the collective memory that is built from operations that select and consolidate certain memories and versions of the past, even within limits and following certain criteria. In this way, the framing of memories is a resource to maintain the integrity of the social fabric and the functioning of the institutions. However, some memories are relegated to silence or oblivion until they can surface in times of serious crises. 


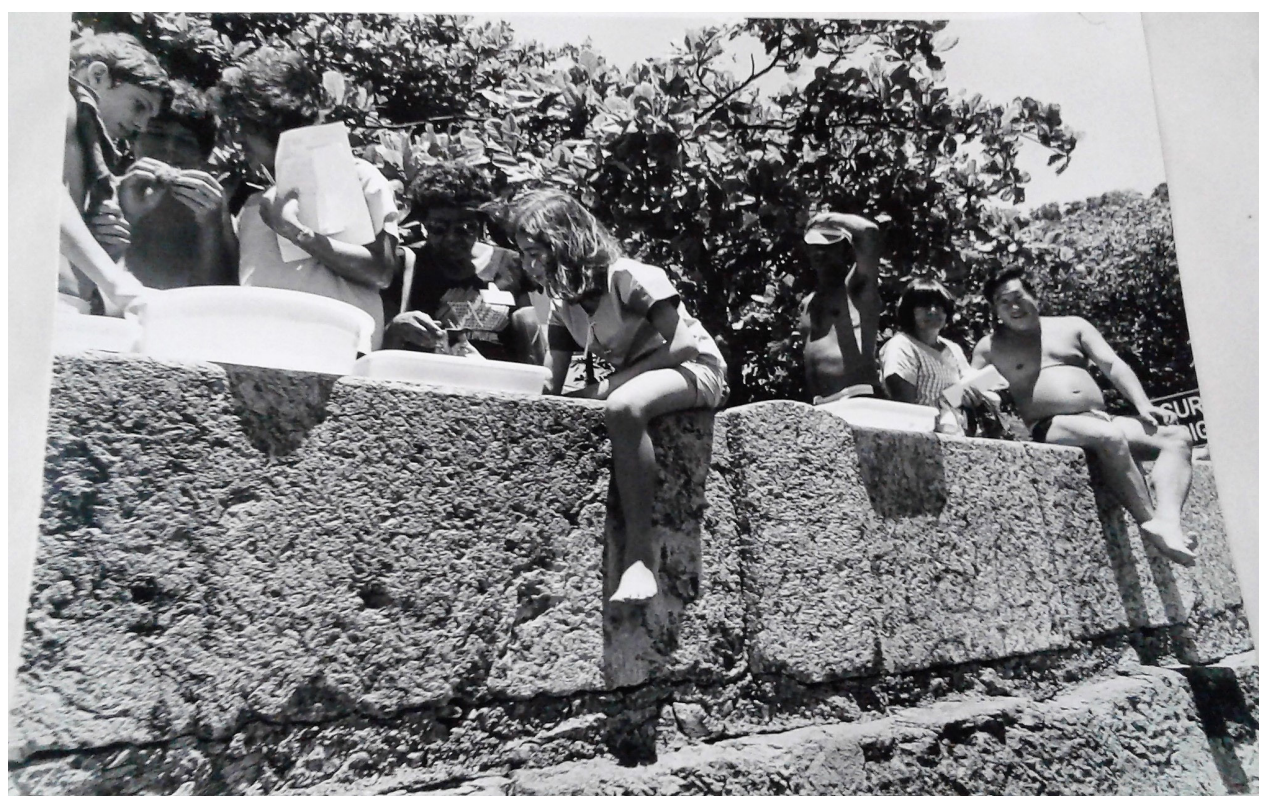

Figure 3. Nilza Vieira's students and what appear to be passersby observing bowls containing marine animals on the wall at Urca beach

Source: Nilza Vieira’s personal photographic collection

Nilza's narrative emphasizes her attitude as a cautious and organized teacher, who was also close to her students. Her speech portrays a ritualized teaching work, surrounded by an almost magical aura about the fieldwork class that was taught. The selection of photographs and the speeches that correspond to the reading and interpretation of each of them by the interviewee are also factors that serve the ritualizations. The images are objects of regulated exchanges, portraying intense events in social life and reaffirming the unity of groups (Bourdieu, \& Bourdieu, 2006), something also explicit in the story told by Nilza Vieira. However, the teacher also made a reservation about the way in which the student body was regulated, considering the care for the life and well-being of her students in a field environment, something consistent with a responsible teaching attitude.

As not all the children under her supervision knew how to swim, former students of Nilza who were taking undergraduate courses in biological sciences at the time were also invited to participate in the fieldwork classes, assisting in the collection and return of marine animals to their habitats:

Those who knew how to dive would, but those who did not know did not dare, because, if it went wrong, the teacher would be held responsible. And then everyone would be forbidden to continue doing it, so only those who knew how to dive would dare. 


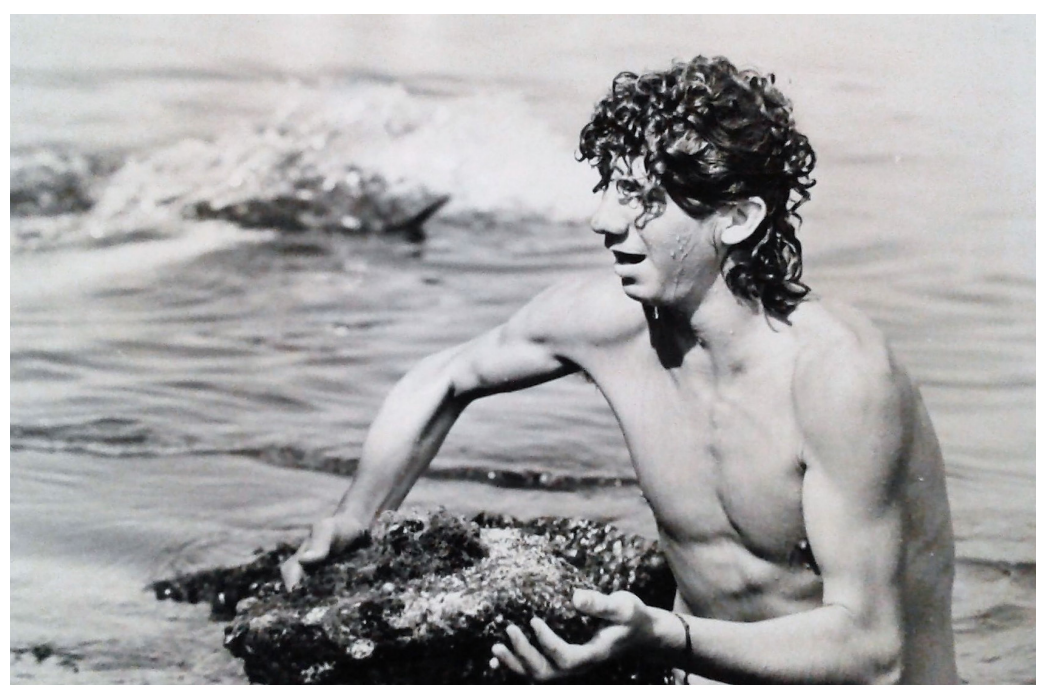

Figure 4. Former EMCCB student, then undergraduate student in biology, acting as a volunteer assistant in the fieldwork class to collect marine animals at Urca Beach

Source: Nilza Vieira’s personal photographic collection.

In a special way, Figure 4 invites us to notice the impression clearly conveyed by a former student of Nilza Vieira at EMCCB when emerging from the sea carrying samples of biological material. The photographed subject and the photographer's own angle suggest the intention of conveying the idea that this was a solemn moment to be revered. At the same time, this deference in the posture assumed by the boy while being photographed carries a sign of attempt to control the objectification of his own figure operated by the photographic portrait (Bourdieu, \& Bourdieu, 2006). The selection of this photograph to compose the narrated story may also have been done with the intention of emphasizing that there were adults who dived into the sea during the fieldwork class to perform the most dangerous work.

This cautious approach brought in her speech and made explicit by the image can lead us to focus on her responsibility for the physical integrity of the children and on the judgment made by her peers. After all, it went against the hegemonic school culture and teaching practices that value expository classes. In addition, we know that school subjects are organized from disputes and negotiations held in disciplinary communities ${ }^{8}$ (Goodson, 1997). Thus, teachers who defended the "Innovation Movement", aligned with Nilza's perspective, would tend to approve of her teaching approach, but other colleagues, in internal disputes at school (or among schools) could hold her accountable and penalize her in the face of any problem.

Therefore, as Santos and Selles (2014) point out, it is necessary to understand the values and interests of the subjects involved in the elaboration and circulation of ideas

8 Disciplinary communities are heterogeneous social groups formed by teachers, researchers and other professionals who constitute and mobilize the school subjects. Such groups compete for resources and power, being able to make use of certain curriculum standards (Goodson, 1997). 
related to the school curriculum. This favors the understanding of teachers' sociability and solidarity networks, allowing us to find evidence about certain speeches and their influences in disputes around the science school subject. In this sense, there were speeches that valued lab experimentation, work with educational biological collections and field trips, all practically contemplated by the activity proposed by Nilza Vieira and emblematically represented in the photographs in which students study the anatomy of animals recently collected on the rocky shore of Urca Beach (Figures 5 and 9). However, the air of informality, euphoria and total student freedom returned to the narrative as soon as the caveat about the consequences of an eventual accident was made:

And the others? The others were vibrating around. A scorching sun, everyone vibrating, some wearing a shirt, others shirtless, with no one taking care [of the students]. There was never a problem. And, what came from the sea, the person who brought it would take it back. It didn't matter that, at school, [the student] was regarded as an unmannerly student, who failed I don't know how many times. There, he or she would know how to dive. He or she would go beyond the teacher, he or she was bigger than the teacher because he or she knew how to dive, he or she knew how to move in the water, discover marine animals and bring them to everyone. He or she grew more than the teacher.

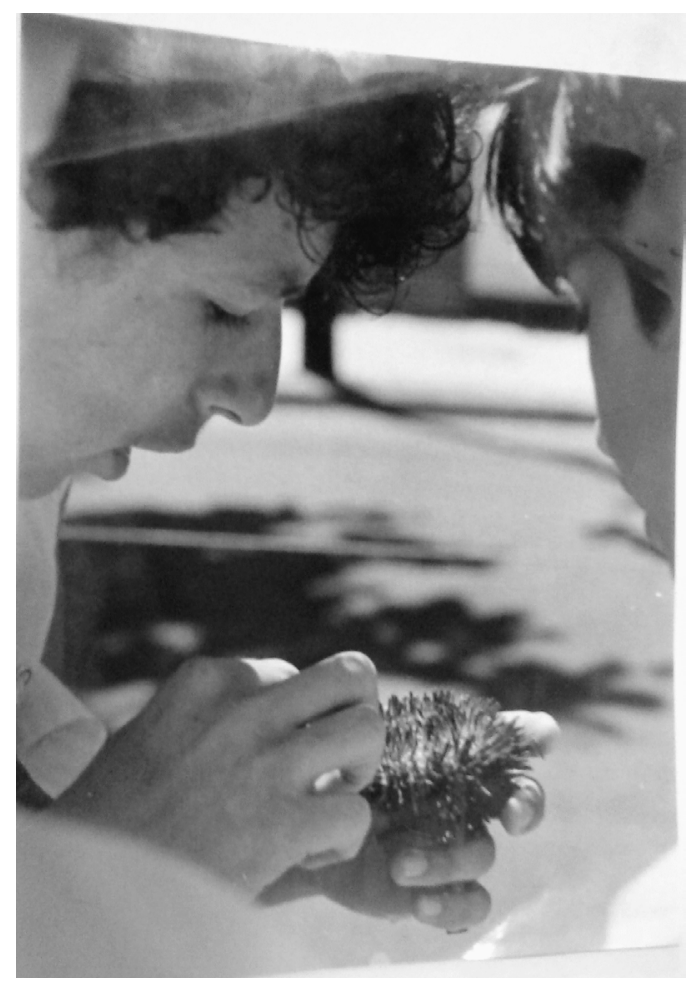

Figure 5. Nilza Vieira's students observing a sea urchin in a fieldwork class at Urca Beach

Source: Nilza Vieira’s personal photographic collection.

The previous excerpt and the Figure 5 represent the importance that Nilza attributed to the development of a leading figure posture on the part of the students. The enthusiasm and relativization of possible stereotypes assigned to her students, expressed 
in her narrative, show a subjective dimension of the construction of her practices as a teacher. In addition, the photographic record leads to a continuous reinforcement of a credible representation of the individuals and actions that integrated that social group, offering a constant update of the daily processes of mutual recognition (Bourdieu, \& Bourdieu, 2006).

Thus, according to Nilza Vieira's testimony, she would value non-authoritarian practices and non-violent communication when dealing with students, interns and colleagues, valuing a horizontal relationship (Figure 6) as she became a teacher:

And then there was the complicity. We didn't need a score of 0 for those who didn't behave and a score of 10 for those who did behave. We needed complicity and it was being created. The bonds were all being made. No one taking care [of the students], no threats, nothing.

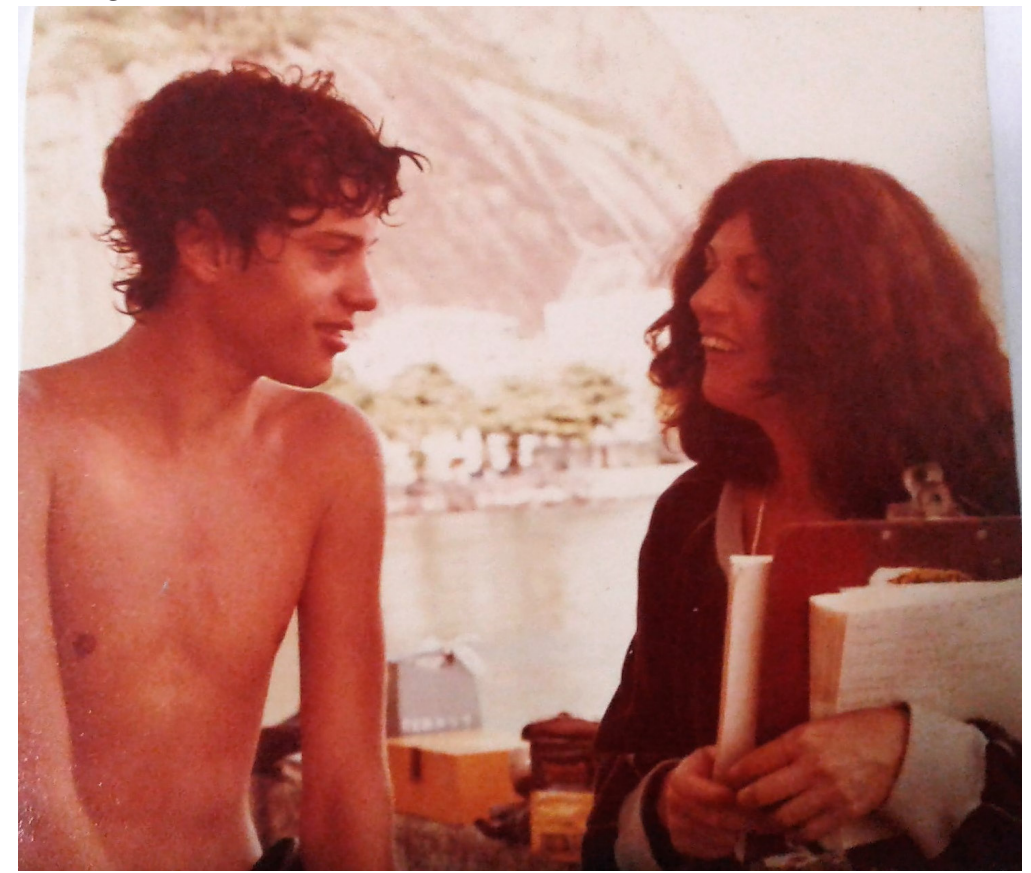

Figure 6. Nilza Vieira next to a student at Praia da Urca

Source: Nilza Vieira’s personal photographic collection.

The choice of what would be the capture of such horizontality seems to point out to the image that Nilza Vieira intends to present of herself. It is clear, in this and the other images in which the teacher is interacting with her students, that what should be learned by the reader of the photograph is not exactly the figures of the teacher and the student, but rather the roles and social relationships built in that context (Bourdieu, \& Bourdieu, 2006). To this we can add the criticism that the teacher makes about the school evaluation system that scores students - and not their performance -, a confusion to which she does not seem to want to incorporate in her teaching proposal, at least in the field trips recorded in the photographs.

The notorious emphasis on students' autonomy, which unfolded in the possibility 
of teaching one another or self-managing without constant teacher intervention in these processes, may indicate a central issue in her establishment as a teacher enrolled in a complex socio-educational context. This way of orienting her practice also refers to the "Science Innovation Movement", re-signifying the centers of interest and the centrality of the student present in the active education defended by the 1930s New School Movement (NSM), as suggested by Abrantes and Azevedo (2010). For the authors, more than introducing active methodologies, in the "Science Education Innovation Movement" the NSM agenda is gradually reframed by the influence of subjects and scientific practices in curricular decisions that, nonetheless, fulfill another agenda and compete for power with educators.

In addition, at that time Brazil was going through an authoritarian regime and so the criticism of the arbitrary character of the evaluation in school subjects could mean a certain distance that the teacher would also like to emphasize. And, more than that, it can help us to understand the representations that the teacher would have about herself and the relationships she established with the other school actors based on her experience (Delory-Momberger, 2012), presenting herself as a teacher who sought to elaborate and socialize other curriculum patterns and traditions for the science school subject:

And the complicity where, in the same story, each person occupied their space without having anyone to direct. If they were driving alone, there was a common will, a common search and it happened. And then the little boy who was diving, now, he was the one who was the teacher of the little children or even the big ones, of the people who got together to learn. The parents who passed by with their children, whoever they were, were also teaching.

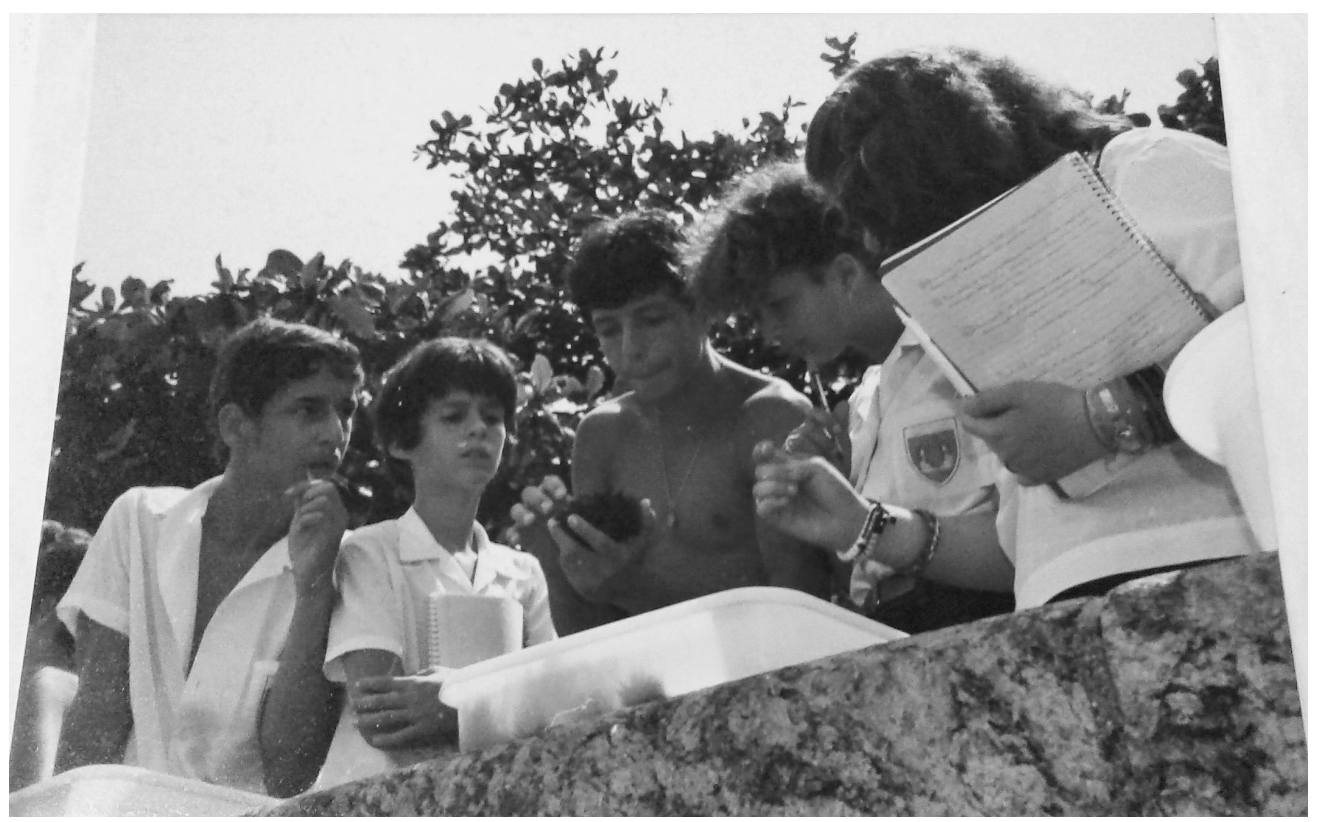

Figure 7. Nilza Vieira's students observing marine animals on the wall at Urca Beach, assisted by a former student and herself as a teacher

Source: Nilza Vieira’s personal photographic collection. 
In this moment of the photobiography, it is worth mobilizing André Chervel (1990), an author who points out that school subjects are unique constructions that are specific to the school, telling us that studying them is valuable for the understanding of the cultural dynamics of the school system. By highlighting the creative character of the school and defending a certain autonomy of educational institutions in relation to the constitution of their curricular matrices, the author helps us to understand that school subjects are also spaces for the production of knowledge, recognizing disciplinary production processes that are inherent to school institutions. In this way, Nilza Vieira's narrative refers to this perception of Chervel when she creates ways of teaching that differ from others conventionally employed. The production of knowledge by school actors seemed to be so eloquent that, according to Nilza, it even caused surprise in those who came across her class in that space:

And then the surprise: what school is this? They thought it was a very expensive private school in the South Zone [wealthy region of Rio de Janeiro] and we were very proud to say: Camilo Castelo Branco Municipal School. It is a public school. Everyone taught. Those who had learned could teach. Those who have the knowledge, teach, and the others learn.

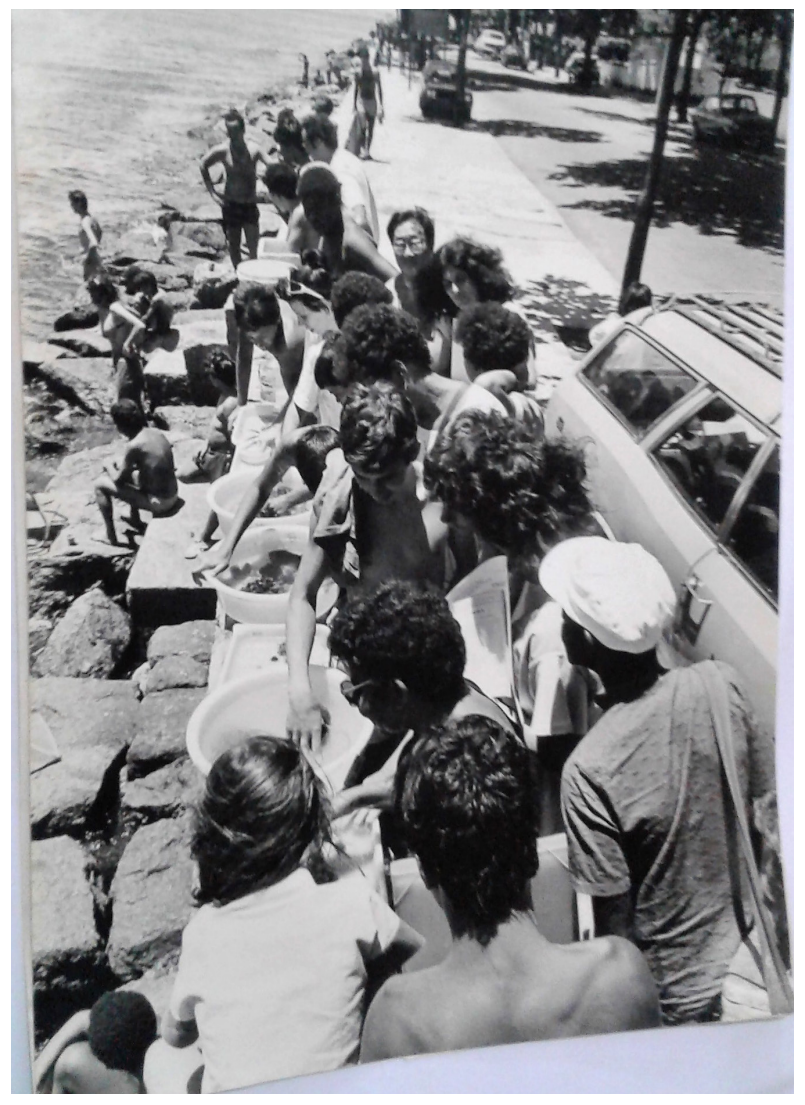

Figure 8. Nilza Vieira's students and what appear to be passersby watching the class on marine animals at Urca Beach 
In view of these practices and representations that gave plural meanings to the way in which the science school subject seemed to be produced by the teacher on a daily basis, there were also other clear allusions to the ideas of the "Science Education Innovation Movement", considering that there was an appreciation of academic perspectives when working with school knowledge: the focus of the work is on knowing the biodiversity of the beach, understanding the evolutionary adaptations of living beings and categorizing them according to the taxonomic classifications prevailing at the time. In addition, when evoking socially prestigious speeches, the report of the pride felt while saying the name of the public school, as a reminder, may be an indication of the factors she considers to have helped her to obtain social recognition in the face of the standards forged by the good science teacher standard of the time, within the framework of the ideas of the "Science Education Innovation Movement". Such emphasis refers to "value as currency in the market for social identity", as stated by Goodson (1997, p. 27)

But if others learn, they can also teach. So there was a continuous multiplication: those who had learned, taught. As everyone learned because everyone knew how to teach very well, everyone could teach. There was no such difference between teacher and student.

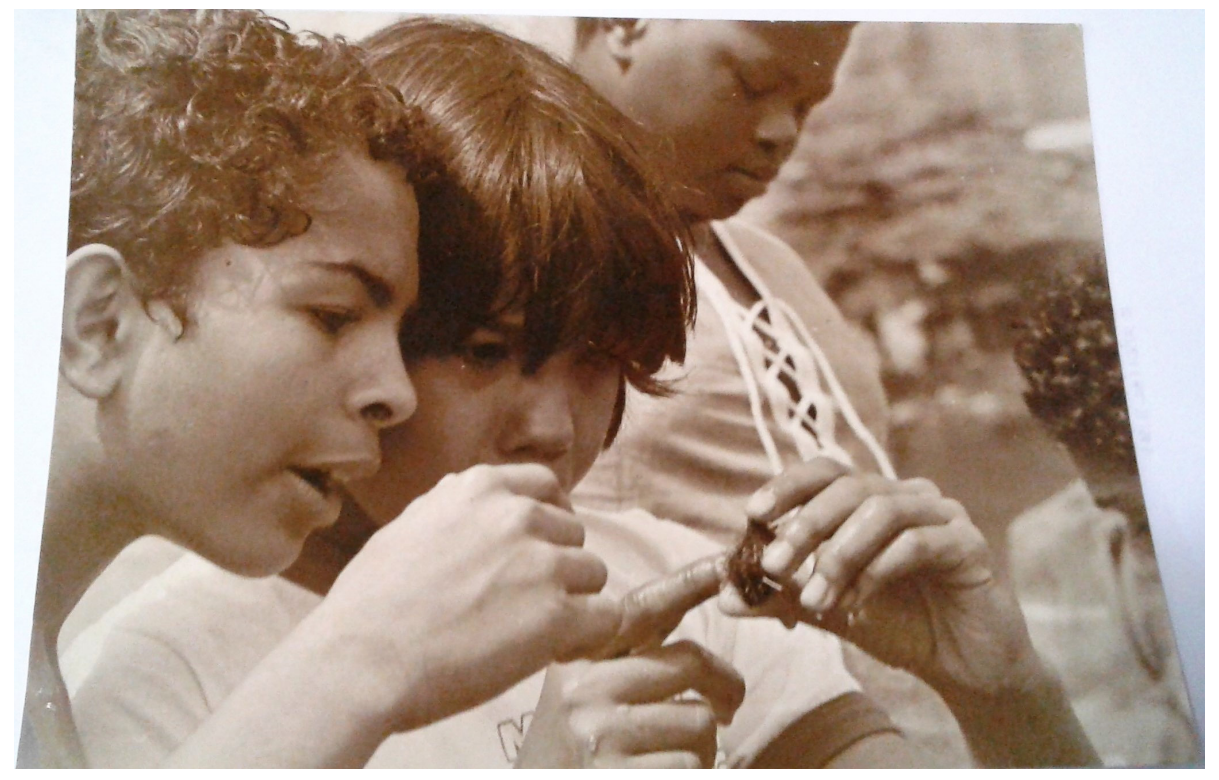

Figure 9. Nilza Vieira's students handling a marine animal in a fieldwork class

Source: Nilza Vieira's personal photographic collection.

Once again, in view of the discourse that reinforces that everything went very well and that everyone was able to teach each other without distinction, it is necessary to pay attention to the risk of monumentalization (Le Goff, 1996) of Nilza Vieira's experience as a science teacher at Camilo Castelo Branco School. This is because memories, both individual and collective, are made by memories and lapses, the result of conscious manipulations or not. Therefore, the memories, as well as the other tracks and clues left by/about/in the past, are the productions of the subjects and their times in the present moment, and in the case of this research, in the presentation of the photographs and 
their justifications.

In this sense, it is possible to indicate that, at least for the students, they were not all the same in relation to the student-teacher binomial. This was perceived by the teacher herself, as it is clear in the excerpt below. In it, there is also reference to one of her colleagues from the undergraduate course, Walter de Mello Veiga da Silva, also working as a science teacher at EMCCB and co-author of her book (Vieira et al., 1970, 1972). Such practices are associated with the undertakings of the "Innovation Movement", which sought to forge new traditions for the teaching of scientific school subjects, but also, as Cassab (2015) points out, aimed at guaranteeing the social prestige of science amid the processes of strengthening scientific institutions in the country and the modernization of school systems:

Everyone came together and the greatest pride is that they [the students] always thought that I always knew more. They never abused my authority, because they thought I always had more to teach. It was always up to me to invent more, and for generations and generations. Ten years before, Walter had been there in the same position with other students, wearing other clothes. My freest [students], those more dressed, doing the same thing. And sometimes those same things were worth a week's trip to Paris, a prize for one that was split into three. ${ }^{9}$ And as this was an ongoing experience, the story continued.

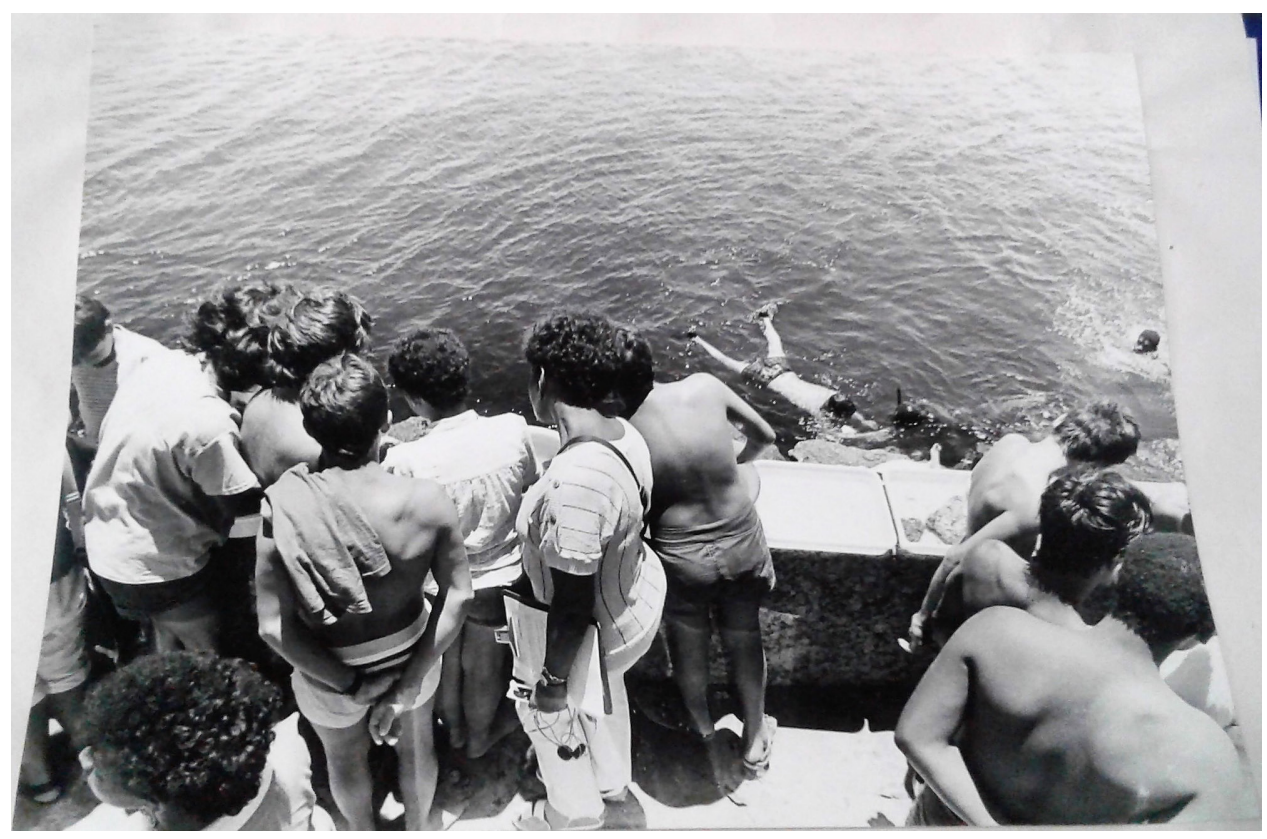

Figure 10. Nilza Vieira's students, and what appear to be passersby, watching and collecting marine animals in Urca

Source: Nilza Vieira’s personal photographic collection.

9 According to information provided at another point in her testimony, Nilza states that in 1971 her co-worker, Walter Veiga da Silva, enrolled in a project he had developed aimed at teaching science in a competition whose main prize was a trip to Paris. He won the contest and shared the prize among three students who participated in the project. Nilza Vieira, on leave due to the death of her husband, did not participate directly in this project. 
In this excerpt, despite the horizontality in the teacher-student relationship, it is evident that the authority was hers. This also seems to be based on how much she was aware of the knowledge she had and what she was able to build together with students and interns. Thus, it seems to us that horizontality was configured more as a principle for teaching and her belief in it is consistent with the teaching intentionality that Forquin (1992) talks about. On the other hand, when informing that her colleague in the previous decade had already taken a class in the field of a similar format, such testimony can align with her assumption that the teaching approach would be stabilized. In commenting on the award, she seems to want to legitimize this approach.

In addition, supported by the reflections of Bourdieu and Bourdieu (2006) on photography as a source for understanding the social relations of the past, it is up to us to look carefully at the issue of students' clothing. In the image, we see that there are students dressed in different ways, while the interviewee signaled the existence of a significant difference between what was encouraged by her - greater freedom in the dress code - and by her colleague Walter in this regard. When analyzing the insertion of Nilza Vieira in her disciplinary community (Goodson, 1997), at least in her reference to Walter Veiga da Silva, it seems to us that her flexibility may be related to the feeling of belonging and notoriety within such a group, since at the beginning of the 1970s, the teacher already exhibited a certain singularity for having written science textbooks and having worked at CECIGUA. Thus, not by chance, the spectacle offered to those who passed by, who, according to Nilza, found themselves inserted in the fieldwork class - despite the informality that was theoretically present in the activities -, can also be understood as another facet of the search to reinforce such prestige and recognition:

Whenever we approached there, the people already surrounded us and knew what was going to happen. It was a point of honor for us to return most animals to the sea. Then the animals were kept in bowls with water that was always renewed so that they would not die and, when it was time to leave, they were returned to the ocean. It was when the people protested: "But why are you going to give it back? Why don't you take it?".

In addition to being monumentalized as the one who not only taught knowledge about marine organisms, the reference to the "point of honor" when returning animals to the sea illustrates the appreciation of animal life and the care for the environment. Thus, she taught lessons on environmentalism, indicating that she was attentive and anticipated ideas of environmental education integrated with the science school subject, something that intensified from the 1980s, as indicated by Fracalanza (2009) and Gomes (2008).

On the other hand, at that moment, when an intense massification of the public school system and the beginning of the precarious processes of the teaching profession were taking place (Cunha, \& Góes, 2002), a curious adaptation developed by Nilza Vieira and her colleagues to maintain an aquarium of seawater at school was produced:

So the beautiful animals were all returned alive to the sea. And a few of them, those that we could keep alive, were taken to the classroom, to school, in our seawater aquarium, 
adapted from a water tank, which was much cheaper than glass. The animals were kept there.

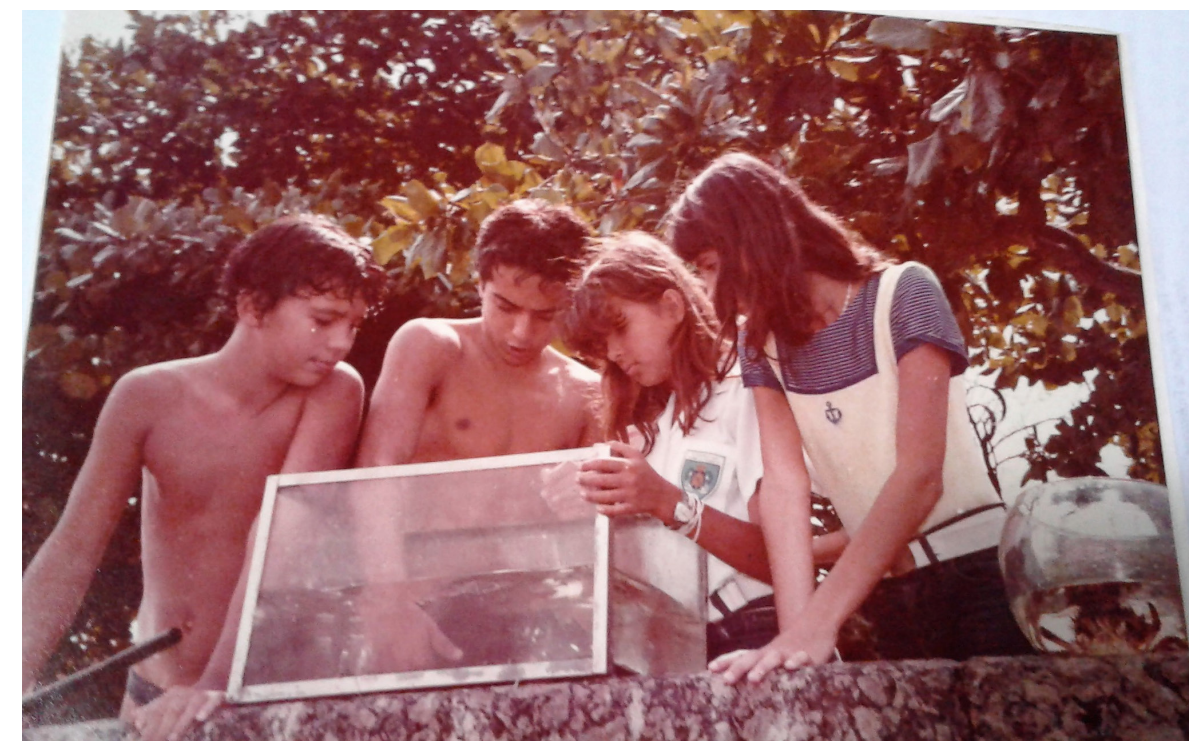

Figure 11. Nilza Vieira's students in a fieldwork class handling marine animals in an aquarium Source: Nilza Vieira's personal photographic collection.

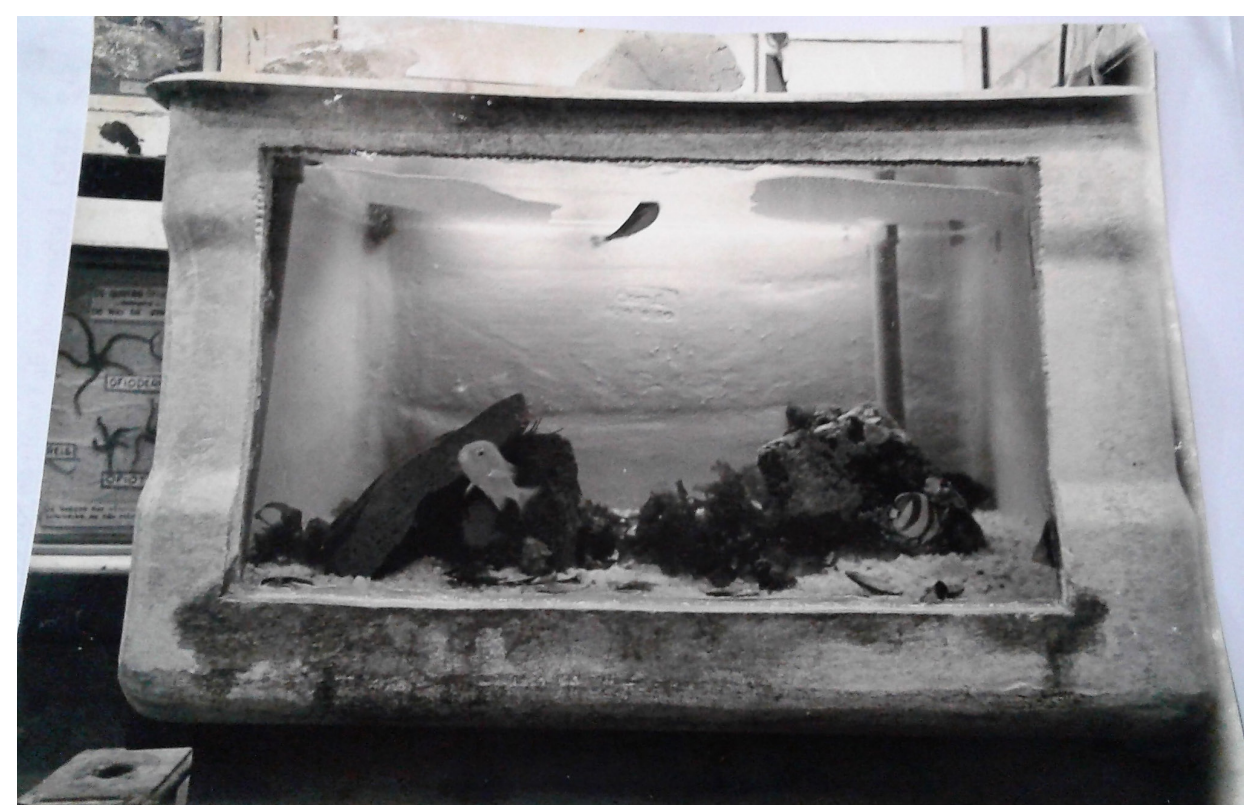

Figure 12. Example of an aquarium adapted from a water tank

Source: Nilza Vieira’s personal photographic collection.

This improvisation for the construction of the aquarium was also in line with the principles of the "Innovation Movement", since it argued in favor of the use of materials available on a daily basis for the manufacture of scientific instruments and devices and the elaboration of activities and experiments. In addition, it was expected that the 
curricula of the science school subject would favour the integration between different areas of scientific knowledge - such as physics, chemistry, biology and the emerging environmental education - and be based on experimental teaching approaches.

At that time, the ideas of "science put into practice", "teaching by rediscovery" and the redefinition of the "project method", along with the defense of Integrated Science for Elementary Education and the Short Degree courses (Ayres, Lima-Tavares, Ferreira, \& Selles, 2012). Such propositions emphasized the scientific research process in the classroom, the valuing of practical activities and the reorganization of contents for an even greater curricular integration of the areas of scientific knowledge so that students develop more "scientific" attitudes when faced with everyday problems (Barra, \& Lorenz, 1986; Fracalanza, 2009). Forged by speeches that indicated such approaches as solutions to educational difficulties, it was also up to the science school subject to develop a "critical spirit" in the student body (Fracalanza, 2009). Knowledge, therefore, would not be contemplative, but would be placed in a practical way at the service of questions involving identification and investigation of problems, elaboration and testing of hypotheses, data analysis and experimental verifications (Lorenz, 2004).

Interestingly, Nilza Vieira emphasizes the impact that occurred in the training of the students who had been educated in accordance with these principles - and who later pursued university studies in biological sciences - to explain the reason why many of them wished to help her in the fieldwork classes as interns:

In this scenario, where a child would teach another child, in this movement of one teaching the other, we encouraged the university students to teach very small children. Because he [the intern] had also been a child-teacher in his time. He had also learned and, here, he was rescuing this story, he was giving back to the school the knowledge he had accumulated as he got older.

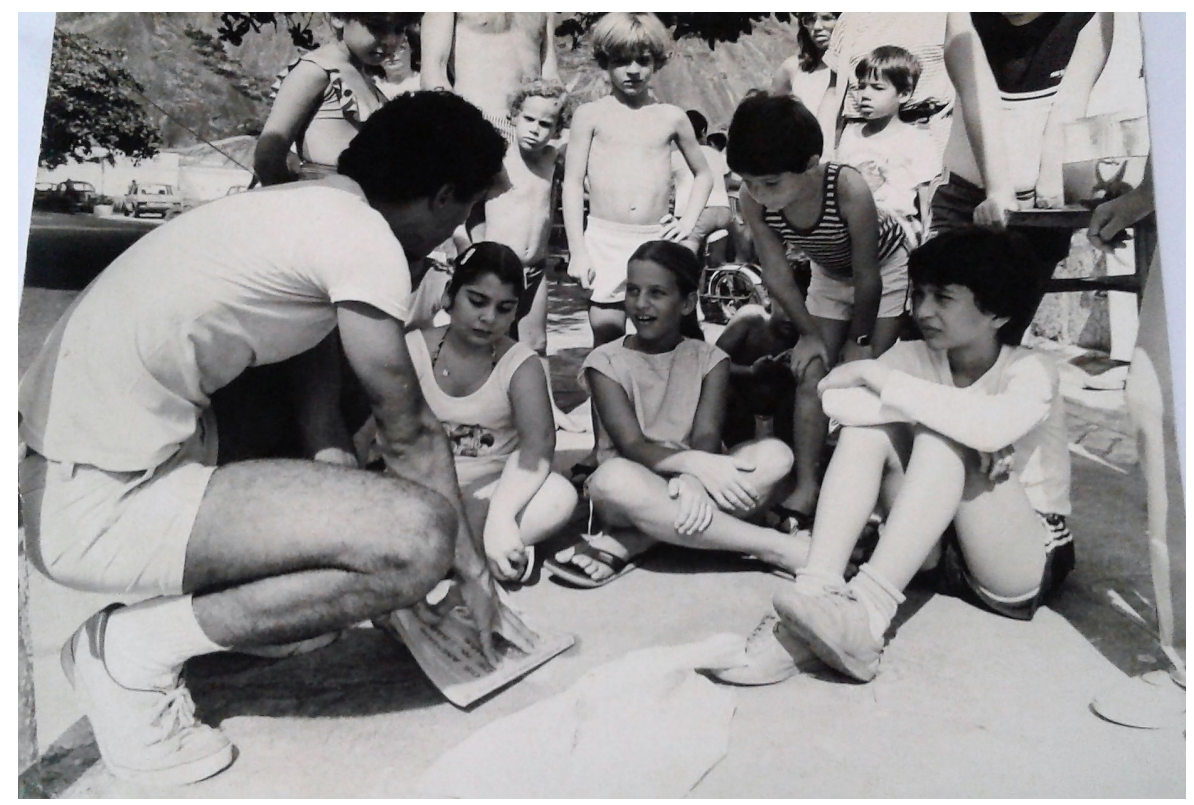

Figure 13. An undergraduate trainee talks to students in a fieldwork class at Urca Beach

Source: Nilza Vieira’s personal photographic collection. 
Finally, our interviewee's photobiography was completed with the return to the photo of Doctor Moisés (Figure 1), which started the narrative, to denote that she found meaning in her professional practice by establishing similarities between her profile and that of the teacher she revered so much. Thus, Nilza seems to want to make explicit her belief that teaching traditions are learned from good examples. Likewise, the method she used and her confidence in a horizontal teaching method are capable of inserting public school students into social functions more valued than teaching itself. Or at least reaffirm, at the same time, that she attributed fame to teachers who, according to her judgment, stood out:

And in this coming and going we train people for the world. Here is a fact that made me proud: José Carlos, my 5th grade student, became a famous cardiac surgeon. Like doctor Moisés, who was the beginning of my story, he [José Carlos] was a famous teacher, in my opinion.

By taking pride and part in these photographs, Nilza Vieira seems to have wanted to ensure that there would be a material testimony of her teaching practices. This testimony is also capable of advocating for her dignity and probity as a teacher in case of being questioned about it. Thus, we are faced with a way of knowing and analyzing the uniqueness of the practices and worldviews contemplated in Nilza Vieira's speech. The procedural character of the biographical activity, with its hesitations, omissions and hyperboles, provides us with clues as to how our interviewee attributed shape and meaning to the experiences and events that crossed her professional trajectory in the face of social reality, while she consolidated herself as a Science teacher (Delory-Momberger, 2012).

\section{Final considerations}

In this text, we present photobiography as a methodological device that inspired this research, based on reflections from the sociological field that deal with comprehensive approaches and seeking to connect such approaches with consolidated authors in the history of education and the curriculum. We conducted an exercise that, we believe, has the potential to enrich the production of the history of the science school subject.

Thus, in view of the demand for new research that relates the professional trajectories of teachers in this school subject with its curricular transformations, the use of the photobiographical device allows the comprehension and the understanding of bridges between life stories, professional training, teaching performance and teaching conceptions. In this scope, we also focus on the trajectory of science teacher Nilza Vieira, recognized as a teacher from Rio de Janeiro who engaged in the "Science Education Innovation Movement", developed in Brazil in the middle of the last century. With the activation of the photobiographical device, we were able to get in touch with some of her educational concepts and teaching practices, probably the most relevant ones.

In our study, we approached these aspects when analyzing activities developed by the teacher in fieldwork classes, conducted at Urca Beach, in Rio de Janeiro. Such 
classes were open to the public and students and interns worked by collecting, handling, observing and studying the biology of marine animals. Investigating the portraits and problematizing her narrative, we list some considerations and raise reflections throughout the photobiography on the teacher's education, performance, professional trajectory and experience.

Thus, from the construction and mobilization of the photobiographical device, it is possible for the interviewee to simultaneously connect the oral source with the imaginary source in the production of a denser narrative in directions that can be explored in the research on the history of the curriculum of the science school subject. However, if the photobiographical contribution carries new opportunities for producing narratives about the past, some caveats also need to be made about its limits and challenges.

The first is that, given the culture of forgetfulness (Nunes, 2004) cultivated in Brazilian society, it can be difficult to find photographs that record teaching practices and curricular constructions carried out in the past. If, today, photographing is an ordinary activity, we cannot ignore that until the end of the 2000s, the records were not abundantly made for several reasons.

The second is that working with the photobiographical device requires a narrator who can consistently tell a story about the photographs. Sometimes photographs may be available, but there is no one to narrate them. This means that, like all oral history work, there have to be lucid subjects who can be interviewed. The more distant from the present is the time frame of the research, the greater the difficulty in finding them until it becomes impossible to locate living people to act as deponents.

It is also essential to emphasize that memories are subjective constructions about the past, updated and renewed in the present time, capable of reconstituting representations and interpretations (Delgado, 2011). Therefore, it is important that we are aware of the limitations and imperfections of operating with them: there is no impartiality or neutrality and it is necessary to show conflicts and dissent in the narrative constructions (Joutard, 2000; Portelli, 1997). Thus, adding photobiography to documentary research and associating them with other sources is important for the consolidation of a solid framework that contributes to reassess and destabilize certainties about the history of the science school subject.

We also believe that a last methodological reflection on photobiography is pertinent: who owns it? The researcher or the interviewee? The photos selected as a source for the photobiographical device are not photobiography in themselves. The person who produces it is the researcher, ultimately, in interaction between the selection that the interviewee makes and the narrative constructed in a dialogical way in the interview. About the selection, one could ask: why these photographs and not others? What seems to have encouraged the interviewee to take them in a certain way? For what purposes were they made? Were they used at other times? Thus, photobiography meets the reflections brought about memory (Le Goff, 1996; Nora, 1993; Pollak, 1989, 1992): it is being narrated in the present, subjected to the conditions of data production. Therefore, 
it is not spontaneous or given a priori. Another point to be mentioned is that several other social, cultural, pedagogical and historical aspects could be addressed from the examination of the photographic material. From the moment we take photographs and other images as historical sources, a range of questions and reflections can be elaborated based on these records. Thus, multiple analyzes and debates are liable to be constructed based on the interests and focus of research and the questions formulated (Burke, 2004).

Finally, in spite of the considerations above, we raise one last reflection: given the socio-historical scenario, currently experienced in Brazil and in the world, of worsening totalitarianism and historical revisionism compliant with authoritarian regimes, is it possible or desirable to ignore such investigative procedures that allow us to amalgamate the experiences and feelings of the subjects - ordinary people, but also members of historical movements - when writing our versions for the history of the science curriculum?

\section{References}

Abrantes, A. C. S., \& Azevedo, N. (2010). O Instituto Brasileiro de Educação, Ciência e Cultura e a institucionalização da ciência no Brasil, 1946-1966. Boletim do Museu Paraense Emílio Goeldi. Ciências Humanas, 5(2), 469-492.

Ayres, A. C. M., \& Selles, S. E. (2012). História da formação de professores: diálogos com a disciplina escolar ciências no ensino fundamental. Ensaio: Pesquisa em Educação em Ciências, 14, 95-107.

Ayres, A. C. M., Lima-Tavares, D., Ferreira, M. S., \& Selles, S. L. (2012). Licenciaturas de curta duração (1965 e 1974) e disciplina escolar ciências: aproximações sócio-históricas. In S. E. Selles, \& M. Cassab. (Orgs.). Currículo, docência e cultura (pp. 53-74). Editora da UFF.

Azevedo, M. (2020). Entre a bancada e a sala de aula - A experimentação no período de ouro do Ensino de Ciências. Appris Editora.

Azevedo, M., Selles, S. E., \& Lima-Tavares, D. (2016). Relações entre os movimentos reformistas educacionais do ensino de ciências nos Estados Unidos e Brasil na década de 1960. Educação em Foco, 21, 237-257. https://doi.org/10.22195/2447-5246201621 19665

Barra, V. M., \& Lorenz, K. M. (1986). Produção de materiais didáticos de ciência no Brasil, período: 1950 a 1980. Ciência e Cultura, 38(12), 1970-1983.

Berteaux, D. (2009). Metodologia do Relato de Vida em Sociologia. In N. M. Takeuti, \& C. Niewiadomski (Orgs.). Reinvenções do sujeito social: teorias e práticas biográficas (pp. 23-32). Sulina.

Bertaux, D. (2014). A vingança do curso de ação contra a ilusão cientificista. Civitas, $14(2), 250-271$.

Bourdieu, P. (1996). A ilusão biográfica. In J. Amado, \& M. M. Ferreira (Orgs.). Usos e Abusos da História Oral (pp. 183-191). Editora da Fundação Getúlio Vargas. 
Bourdieu, P., \& Bourdieu, M. C. (2006). O camponês e a fotografia. Rev. Sociol. Polit, 26, $31-39$.

Bruno, F. (2014). Fotobiografia: uma proposta antropológica e estética. Revista Espaço Acadêmico, 163, 9-20.

Burke, P. (2014). O Testemunho das Imagens. In: P. Burke. Testemunha Ocular: história e imagem (pp. 11-24). EDUSC.

Cassab, M. (2010). A produção em História das Disciplinas Escolares pela escrita de pesquisadores brasileiros. Revista Brasileira de História da Educação, 23, 225-251.

Cassab, M. (2015). O movimento renovador do ensino das ciências: entre renovar a escola secundária e assegura o prestígio social da ciência. Revista Tempos e Espaços em Educação, 8, 19-35. https://doi.org/10.20952/revtee.v0i0.3938

Chervel, A. (1990). História das disciplinas escolares: reflexões sobre um campo de pesquisa. Teoria \& Educação, 2, 177-229.

Cunha, L. A., \& Góes, M. (2002). O golpe na educação. 11. ed. Jorge Zahar.

Delgado, L. A. N. (2011). História Oral: memória, tempo, identidades. 2. ed. Autêntica.

Delory-Momberger, C. (2012). Abordagens metodológicas na pesquisa biográfica. Revista Brasileira de Educação, 17(51), 523-536.

Dubar, C. (1998). Trajetórias sociais e formas identitárias: alguns esclarecimentos conceituais e metodológicos. Educação \& Sociedade, 19(62), 13-30.

Fonseca, M. V. R., Xavier, M. T., Vilela, C. L., \& Ferreira, M. S. (2013). Panorama da produção brasileira em história do currículo e das disciplinas acadêmicas e escolares (2000-2010): entre a História da Educação e a Sociologia do Currículo. Revista Brasileira de História da Educação, 13, 193-225.

Forquin, J. C. (1992). Saberes escolares, imperativos didáticos e dinâmicas sociais. Teoria \& Educação, 1(5), 28-49.

Fracalanza, H. (2009). Histórias do ensino de Biologia no Brasil. In S. E. Selles, M. S. Ferreira, M. A. Barzano, \& E. P. Q. Silva (Orgs). Ensino de Biologia: histórias, saberes e práticas formativas (pp. 25-48). EdUFU.

Fracalanza, H., Amaral, I. A., \& Gouveia, M. S. F. (1987). O ensino de ciências no primeiro grau. Atual, $124 \mathrm{p}$.

Gomes, M. M. (2006) Conhecimentos ecológicos em livros didáticos de ciências: aspectos sócio-históricos de sua constituição. (Tese de Doutorado em Educação). Programa de Pós-Graduação em Educação da Universidade Federal Fluminense, Niterói.

Gomes, M. M., Selles, S. E., Lopes, A. C. (2013). Currículo de Ciências: estabilidade e mudança em livros didáticos. Educação e Pesquisa (USP. Impresso), 39, 477-492. https:// doi.org/10.1590/S1517-97022013000200013 
Goodson, I. F. (1992). Dar voz ao professor: as histórias de vida dos professores e seus desenvolvimentos profissionais. In A. Nóvoa (Org.). Vidas de professores (pp. 63-78). Porto.

Goodson, I. F. (1997). A Construção Social do Currículo. Educa.

Goodson, I. F. (2007). Questionando as reformas educativas: a contribuição dos estudos biográficos a educação. Pro-posições, 18, (2), 17-37.

Goodson I. F. (2015) Narrativas em educação: a vida e a voz dos professores. Porto Editora.

Joutard, P. (2000). Desafios à História oral do século XXI. In M. M. Ferreira, T. Fernandes, \& V. Alberti. (Orgs). História Oral: desafios para o século XXI (pp. 31-46). Fundação Getúlio Vargas.

Krasilchik, M. (2000). Reformas e realidade: o caso do ensino das ciências. São Paulo em Perspectiva, 14(1), 85-93.

Le Goff, J. (1996). Memória e História. Editora da UNICAMP.

Lelis, I. A. O. M. (2014). A construção social da profissão docente no Brasil: uma rede de histórias. In M. Tardif, \& C. Lessard (Orgs.). O ofício de professor: história, perspectivas e desafios internacionais (pp. 54-66). 6 ed. Vozes.

Lelis, I. A. O. M, \& Nascimento, M. G. C. A. (2010). Trajetórias de professores: a pesquisa com histórias de vida. In A. W. P. Mendonça (Org.). História e Educação: dialogando com as fontes (pp. 253-272). 1 ed. Forma e Ação.

Levi, G. Usos da biografia (1996). In J. Amado, \& M. M. Ferreira (Orgs.). Usos e Abusos da História Oral (pp. 167-182). Rio de Janeiro: Editora da Fundação Getúlio Vargas.

Lopes, S. M. C. N. (2013). Professores inesquecíveis: docência e prestígio no Instituto de Educação do Rio de janeiro dos anos 1950-60. In Anais do VII Congresso Brasileiro de História da Educação. Cuiabá, MT.

Lopes, S. M. C. N. (2016). Os notáveis do Instituto de Educação: professores catedráticos do curso normal nos anos 1950-60. Educação em Foco (Juiz de Fora), 21, 157-183. https://doi.org/10.22195/2447-524620162119727

Lorenz, K. M. (2004) As Reformas do Ensino das Ciências no Ensino Secundário Brasileiro nas Décadas de 1960 e 1970. Revista Portuguesa de Pedagogia, 39(1), 97-112.

Loriga, S. (1998). A biografia como problema. In J. Revel (Org.). Jogos de escalas: a experiência da microanálise. Editora da Fundação Getúlio Vargas.

Lozano, J. E. A. (1996). Prática e Estilos de Pesquisa Histórica Oral Contemporânea. In J. Amado, \& M. M. Ferreira (Orgs). Usos e Abusos da História Oral. Rio de Janeiro: Fundação Getúlio Vargas.

Marandino, M., Selles, S. E., \& Ferreira, M. S. (2010). Ensino de Biologia: histórias e práticas em diferentes espaços educativos. Cortez. 
Nora, P. (1993). Entre memória e história: a problemática dos lugares. Projeto História. São Paulo, 10, 07-28.

Nunes, C. (2004). Memória e História da Educação: entre práticas e representações. Educação em Foco - História da Educação, 07(12), 01-17.

Pollak, M. (1989). Memória, esquecimento, silêncio. Estudos Históricos, 2(3), 3-15.

Pollak, M. (1992). Memória e identidade social. Estudos Históricos, 15(10), 200-212.

Portelli, A. (1997). O que faz a História Oral diferente. Projeto História, 14, 25-39.

Santos, M. C. F., \& Selles, S. E. (2014). A produção da disciplina escolar história natural na década de 1930: os livros didáticos de Waldemiro Potsch para o ensino secundário. Cadernos de Pesquisa em Educação, 19, 45-68. https://doi.org/10.22535/cpe.v1i39.10729

Scarton, J. G. E., \& Selles, S. E. (2012). Narrativas docentes de práticas em educação ambiental na Escola Municipal Camilo Castelo Branco. In Anais do VI Encontro Regional de Ensino de Biologia do Rio de Janeiro e Espírito Santo. Rio de Janeiro, RJ.

Vieira, C. O. F., Vieira, N. B. P., \& Silva, W. M. V. (1970). Cadernos MEC: Iniciação à ciência. MEC/FENAME.

Vieira, C. O. F., Vieira, N. B. P., \& Silva, W. M. V. (1972) Iniciação à ciência: guia metodológico para cadernos MEC. MEC/FENAME.

Rodrigo Cerqueira do Nascimento Borba ${ }^{10}$ https://orcid.org/0000-0002-4504-5793 Universidade Federal Fluminense Niterói, Rio de Janeiro, Brazil rodrigocnb@gmail.com

Sandra Escovedo Selles

${ }^{1}$ https://orcid.org/0000-0002-7921-0478 Universidade Federal Fluminense (UFF) Niterói, Rio de Janeiro, Brazil escovedoselles@gmail.com

Submitted on 10th April 2020

Accepted on 03rd June 2020

Published on 29th June 2020 